\title{
HUBUNGAN POSISI DAN LAMA DUDUK DENGAN NYERI PUNGGUNG BAWAH (NPB) MEKANIK KRONIK PADA KARYAWAN BANK
}

\author{
${ }^{1}$ Aron Pirade \\ ${ }^{2}$ Engeline Angliadi \\ ${ }^{2}$ Lidwina S. Sengkey \\ ${ }^{1}$ Kandidat Skripsi Fakultas Kedokteran Universitas Sam Ratulangi Manado \\ ${ }^{2}$ Bagian Ilmu Kedokteran Fisik dan Rehabilitasi Fakultas Kedokteran \\ Universitas Sam Ratulangi Manado \\ Email: aron_pirade@yahoo.com
}

\begin{abstract}
Low Back Pain (LBP) is the most frequent musculosceletal issue found in daily work. Extenuating physical positions comprise $80-85 \%$ of the caues of LBP. In the medical world, a lot of causes of LBP do not identify the pathoanatomical disorders. These factors are e.g.: body in static position while working and the working body position leaning heavily on the vertebra (for example: sitting in a hunched position, sitting upright without back support, or working for unsually long periods of time). Until now in Manado no study has been carried out to show the correlation between LBP and the sitting position, or the duration of work. This study aimed to find out the correlation between chronic LBP and the sitting position or the duration of work among bank employees in one of the goverment banks in Manado. The results showed that there were 69 respondents involved in this study. Chronic LBP was found in 62 respondents $(90 \%)$. Up stright position while sitting was the most frequent position that caused chronic LBP in 28 respondents. The average time used for working with sitting position was 7-8 hours which caused chronic LBP among 31 respondents of the group with the work time from 11.00-13.59. A $P$-value of $0.000(<0.05)$ showed that there was a strong correlation between sitting position and chronic LBP. Duration of work also showed a strong correlation with chronic LBP with a $P$-value of 0.000 . Conclusion: There were strong correlations beween chronic low back pain with sitting position while working and duration of work.
\end{abstract}

Keywords: chronic LBP chronic, sitting position, duration of work, bank employees.

Abstrak:Nyeri Punggung Bawah (NPB) merupakan gangguan muskuloskeletal yang paling
sering dijumpai dalam aktivitas kerja. Faktor mekanik mencakup $80-85 \%$ dari keseluruhan
penyebaNPB. Patoanatomi sering tidak dapat memberikan ketepatan diagnosis NPB oleh
proses mekanik. Faktor mekanik yang mempercepat terjadinya gangguan NPB antara lain
posisi badan yang cenderung statis, posisi badan yang cenderung memperberat kerja tulang-
tulang vertebra seperti posisi badan membungkuk, tegak tanpa sandaran, dan waktu bekerja
yang lama saat duduk. Hubungan NPB dengan posisi dan lama duduk belum pernah
dilaporkan di Kota Manado. Penelitian ini bertujuan untuk mengetahui hubungan posisi dan
lama duduk saat bekerja yang dapat menimbulkan NPB mekanik kronik pada karyawan bank.
Hasil penelitian memperlihatkan dari keseluruhan responden yang berjumlah 69 orang,
didapatkan 62 responden (90\%) yang mengalami NPB mekanik kronik. Posisi duduk tegak
tanpa sandaran merupakan posisi terbanyak menimbulkan NPB mekanik kronik pada 28
responden. Rata-rata lama duduk bekerja $7-8$ jam menyebabkan NPB pada kelompok pukul
$11.00-13.59$ sebanyak 31 responden. Analisis statistik menggunakan uji chi-square 
memperlihatkan adanya korelasi yang kuat $(P=0,000)$ antara posisi duduk dan NBP mekanik kronik Lama duduk juga berkorelasi kuat dengan NBP mekanik kronik $(P=0,000)$. Simpulan: Terdapat hubungan yang kuat antara NBP mekanik kronik dengan posisi dan lama duduk pada karyawan bank.

Kata kunci: NPB mekanik kronik, posisi duduk, lama duduk, karyawan bank.

Nyeri Punggung Bawah (NPB) merupakan gangguan muskuloskeletal yang paling banyak dijumpai dalam aktivitas kerja ${ }^{1,2}$ dan telah lama dikenal oleh masyarakat dunia. Bila tidak ditatalaksana dengan benar, gangguan ini dapat mengakibatkan disability, impairment, bahkan handicap. ${ }^{4,5}$

NPB sering terjadi pada usia produktif. Penelitian di Inggris Raya menunjukkan NPB sebagai penyebab pertama tingkat kecacatan. ${ }^{1}$ Di Swedia (1980-1987), NPB menyebabkan 7-28 juta penderita kehilangan hari-hari kerja. ${ }^{6}$ Prevalensi NPB di Belgia tahun 2004 ialah 85 dari 228 orang $(37,3 \%)$ yang berusia 17-25 tahun, sedangkan di Irlandia tahun 200761 dari 188 orang (32\%) yang berusia $20,3 \pm 2,7$ tahun. $^{7}$

Sekitar $80-85 \%$ etiologi NPB ialah faktor mekanik, yang sering secara patoanatomi tidak dapat memberikan ketepatan diagnosis sehingga dikatakan bersifat nonspesifik. ${ }^{1,5}$ Posisi dan lama duduk dalam bekerja sering diabaikan, padahal kondisi ini penting karena mengandung prinsip ergonomik. Pada lingkungan tempat kerja, duduk merupakan satu dari empat aktivitas yang umum dilakukan. Dua komponen terkait saat duduk yaitu, posisi dan lama duduk. Duduk bekerja mendatangkan gangguan saat bekerja yang dikenal dengan repetitive strain injury (RSI); salah satu RSI yang sering terjadi saat duduk ialah NPB. ${ }^{8-12}$

Pekerjaan yang berisiko menimbulkan NPB mekanik kronik antara lain pekerjaan yang memiliki jam kerja panjang dan mengharuskan karyawannya untuk duduk dalam waktu yang lama pada posisi duduk tertentu. Bekerja di bank merupakan salah satu pekerjaan yang berisiko terkena NPB. Penelitian sebelumnya pada beberapa daerah di Indonesia telah meneliti keterkaitan faktor mekanik sebagai faktor risiko $\mathrm{NPB},{ }^{4}$ namun keterkaitan NPB dengan posisi dan lama duduk di Kota Manado belum pernah dilaporkan.

\section{METODE PENELITIAN}

Penelitian ini bersifat analitik dengan cross sectional design. Penelitian dilaksanakan di salah satu Bank Usaha Milik Negara (BUMN) kantor wilayah (Kanwil) dan kantor cabang (Kacab) di Kota Manado pada bulan November-Desember 2012.

Besar sampel ditentukan dari jumlah responden yang mengikuti penelitian ini. Kriteria inklusi ialah responden terdaftar sebagai karyawan tetap di bank dengan jenis pekerjaan back-office dan rentang usia 20-55 tahun.

Penelitian ini menggunakan kuesioner yang belum tervalidasi. Kuesioner terdiri dari lima bagian yaitu: identitas responden, pertanyaan saringan, waktu duduk (jam) saat mengalami nyeri, posisi duduk paling sering saat bekerja, dan intensitas nyeri.

Analisis data dilakukan dengan uji chisquare untuk mengetahui kemaknaan hubungan antar variabel dependen dan independen. Analisis data menggunakan statistical package for social sciences (SPSS) 17.

\section{HASIL PENELITIAN}

\section{Deskripsi karateristik responden}

Dalam penelitian ini terdapat 69 orang karyawan bank yang bersedia menjadi responden. Deskripsi responden meliputi usia, jenis kelamin, lama kerja (tahun), dan rerata lama duduk karyawan selama satu hari (jam) (Tabel 1). 
Tabel 1. Deskripsi karakteristik responden.

\begin{tabular}{lccclll}
\hline Karateristik & Frekuensi & \% & mean & min & max & std.deviasi \\
\hline Usia & & & 30,93 & 20 & 53 & 7,5 \\
20-30 tahun & 44 & 63,8 & & & & \\
31-40 tahun & 15 & 21,7 & & & & \\
$\quad>40$ tahun & 10 & 14,5 & & & & \\
Jenis kelamin & & & - & - & - & - \\
$\quad$ laki-laki & 35 & 50,7 & & & & \\
$\quad$ perempuan & 34 & 49,3 & & & & \\
Lama kerja (tahun) & & & 7,62 & 1 & 31 & 7,14 \\
1-10 tahun & 54 & 78,3 & & & & \\
11-20 tahun & 9 & 13 & & & & \\
$\quad$ > 0 tahun & 6 & 8,7 & & & & \\
Rerata lama duduk dalam 1 hari (jam) & & & 7,35 & 3 & 10 & 2,013 \\
1-2 jam & 0 & 0 & & & & \\
3-4 jam & 8 & 11,6 & & & & \\
5-6 jam & 14 & 20,3 & & & & \\
7-8 jam & 23 & 33,3 & & & & \\
9-10 jam & 24 & 34,8 & & & & \\
\hline
\end{tabular}

\section{Usia}

Kelompok usia (1) berjumlah 44 responden,dan yang terbanyak dibanding kelompok usia (2) dan (3). Rata-rata usia responden ialah 31 tahun dengan usia termuda 20 tahun dan tertua 53 tahun.

\section{Jenis kelamin}

Jumlah responden berjenis kelamin laki-laki dan perempuan cenderung sama, dimana responden berjenis kelamin 35 orang $(51 \%)$ dan berjenis kelamin perempuan 34 orang $(49 \%)$.

\section{Lama kerja}

Lama kerja responden tertinggi pada kelompok (1) yaitu 1-10 tahun, dengan jumlah 54 orang. Rata-rata lama kerja 8 tahun, serta usia kerja terendah 1 tahun dan tertinggi 31 tahun.

\section{Rerata lama duduk dalam sehari bekerja}

Rerata lama duduk responden sebanyak 9-10 jam dalam sehari yaitu kelompok (5) yang tertinggi dengan jumlah 24 responden, sedangkan lama duduk kerja sebanyak 7-8 jam yaitu kelompok (4) menempati posisi kedua teringgi dengan 23 responden. Rerata lama duduk karyawan per hari 7 jam.

\section{Deskripsi responden yang mengalami NPB}

Dari 69 responden, tercatat 62 orang (90\%) yang mengalami NPB saat duduk bekerja di kantor dan 7 orang $(10 \%)$ yang tidak mengalami NPB (Tabel 2).

\section{Kelompok usia}

Berdasarkan kelompok usia, responden yang berusia 20-30 tahun yang terbanyak menderita NPB, yaitu dari 44 responden terdapat 41 yang menderita NPB.

\section{Jenis kelamin}

Pada penelitian ini tercatat 30 dari 35 responden laki-laki dan 32 dari 34 responden perempuan yang menderita NPB saat bekerja di kantor.

\section{Lama kerja}

Berdasarkan lama kerja seluruh responden ditemukan dominasi pada 
Tabel 2. Deskripi NPB berdasarkan karateristik.

\begin{tabular}{lcc}
\hline \multirow{2}{*}{ Karateristik } & \multicolumn{2}{c}{ NPB mekanik kronik } \\
\cline { 2 - 3 } Usia & & tidak \\
\hline 20-30 tahun & 41 & 3 \\
31-40 tahun & 12 & 3 \\
$\quad>40$ tahun & 9 & 1 \\
Jenis kelamin & & \\
$\quad$ laki-laki & 30 & 5 \\
$\quad$ perempuan & 32 & 2 \\
Lama kerja (tahun) & & \\
1-10 tahun & 48 & 6 \\
11-20 tahun & 9 & 0 \\
$\quad>20$ tahun & 5 & 1 \\
Rerata lama duduk & & \\
dalam 1 hari (jam) & & \\
1-2 jam & 0 & 0 \\
3-4 jam & 7 & 1 \\
5-6 jam & 12 & 2 \\
7-8 jam & 22 & 1 \\
9-10 jam & 21 & 3 \\
\hline
\end{tabular}

responden dengan lama kerja berkisar 1-10 tahun, yaitu 54 orang; 48 responden menyatakan menderita NPB.

\section{Rerata lama duduk bekerja}

Rentang waktu bekerja selama 7-8 jam per hari ditemukan pada 23 responden; 22 orang di antaranya menderita NPB. Pada rentang waktu bekerja 9-10 jam, dari 24 responden terdapat 21 orang yang menderita NPB.

\section{Responden yang mengalami NPB}

Pada penelitian ini, NPB dinilai dari dua hal, yaitu posisi dan lama duduk.

\section{Posisi duduk karyawan bank}

Posisi duduk saat bekerja yang terbanyak mengalami nyeri ialah posisi duduk tegak. Responden yang duduk bekerja dengan posisi duduk tegak yaitu sebanyak 28 orang (Tabel 3).

Dari hasil pengolahan data dengan SPSS 17 antara variabel dependen (data nominal) dengan variabel independen (data nominal) didapatkan nilai $P=0,000$.

\section{Lama duduk karyawan bank}

Dari 62 responden yang mengalami NPB, 30 orang mengalami nyeri pada rentang kerja pukul 08.00-10.59, sedangkan pada rentang pukul 11.00-13.59 terdapat 31 orang (Tabel 3).

Hasil pengolahan data dengan SPSS 17 antara variabel dependen (data interval) dan variabel independen (data nominal) didapatkan $\mathrm{P}=0,000$.

\section{BAHASAN}

Diskusi membahas mengenai data univariat (karateristik subjek penelitian) dan data bivariat hasil analisis menggunakan metode chi-square.

\section{Karateristik subyek penelitian}

Pada penelitian ini tercatat 69 responden, dengan rentang usia 20-53 tahun (rerata 31 tahun). Alemo dan Sayadipour ${ }^{13}$ meneliti NPB mekanik kronik pada 732 responden dengan rentang usia 19-89 tahun (rerata 51 tahun). Jumlah responden yang besar disebabkan oleh karena

Tabel 3. Posisi dan lama duduk bekerja dengan NPB.

\begin{tabular}{|c|c|c|c|c|c|c|c|}
\hline \multirow{2}{*}{$\begin{array}{l}\text { Lama duduk } \\
\text { saat bekerja }\end{array}$} & \multicolumn{2}{|c|}{ NPB } & \multirow{2}{*}{ Total } & \multirow{2}{*}{$\begin{array}{l}\text { Posisi duduk } \\
\text { saat bekerja }\end{array}$} & \multicolumn{2}{|c|}{ NPB } & \multirow{2}{*}{ Total } \\
\hline & Tidak & $\mathbf{Y a}$ & & & Tidak & $\mathbf{Y a}$ & \\
\hline $08.00-10.59$ & 0 & 30 & 30 & Membungkuk & 0 & 27 & 27 \\
\hline $11.00-13.59$ & 0 & 31 & 31 & Tegak & 2 & 28 & 30 \\
\hline $14.00-18.00$ & 0 & 1 & 1 & Rileks & 5 & 7 & 12 \\
\hline Tidak nyeri & 7 & 0 & 7 & & & & \\
\hline Total & 7 & 62 & 69 & & 7 & 62 & 69 \\
\hline
\end{tabular}


penelitian tersebut dilaksanakan dengan rentang waktu yang lebih panjang yaitu tahun 1997-2007.

Pada penelitian ini jenis kelamin responden yang berimbang mirip dengan penelitian Purnamasari et al. $^{14}$ dengan jumlah responden laki-laki 32 orang dan responden perempuan 50 orang. Berbeda dengan karateristik jenis kelamin yang didapatkan oleh Tana dan Halim dengan jumlah responden laki-laki 37 dan perempuan yang jauh lebih besar yaitu 345 orang.

Pada penelitian ini terdapat 54 responden yang bekerja pada bank ini sampai dengan 10 tahun dan hanya 15 responden yang sudah bekerja selama lebih dari 10 tahun. Hasil ini berbeda dengan penelitian Tana dan Halim pada jenis pekerjaan paramedis yang mendapatkan 168 responden dengan lama kerja 1-10 tahun dan 214 responden yang bekerja lebih dari 10 tahun. ${ }^{15}$

\section{Responden yang mengalami NPB terhadap posisi duduk dan lama duduk}

Asosiasi British Chiropractic menemukan $32 \%$ dari populasi penelitian yang berstatus pekerja/karyawan menghabiskan rata-rata 10 jam sehari untuk duduk dalam melakukan pekerjaannya. Setengahnya tidak pernah berdiri saat sementara bekerja sekalipun disediakan waktu untuk beristirahat. ${ }^{16}$ Hal yang terjadi di atas dapat juga ditemukan pada karyawan bank dengan jenis pekerjaan yang menuntut ketelitian dan konsentrasi tinggi dalam menganalisis transaksi uang masuk-uang keluar dari bank, data tunggakan peminjaman uang oleh nasabah, serta lonjakan nasabah yang bertransaksi di akhir tahun. Dengan demikian, bukan saja profesi yang bersifat hipermobilitas (seperti buruh, sopir, dll) yang mempunyai risiko untuk terjadi RSI, namun profesi yang sifatnya hipomobilitas seperti karyawan bank juga rentan terhadap RSI, khususnya NPB mekanik kronik.

\section{Posisi duduk}

Posisi duduk yang paling sedikit mendatangkan nyeri ialah posisi duduk rileks yang ditemukan pada 7 responden; posisi duduk membungkuk 27 responden; dan posisi duduk tegak tanpa sandaran sebanyak 28 responden. Hasil tersebut sejalan dengan penelitian di Universitas Modern Dental oleh Priyanka et al.yang menyatakan bahwa posisi duduk yang paling mengikuti prinsip ergonomik saat bekerja ialah posisi duduk rileks (relax position). Duduk dengan posisi rileks membentuk sudut sekitar 105-125 merupakan sudut yang direkomendasikan para peneliti untuk dilakukan saat duduk bekerja. ${ }^{17}$ Hampir serupa dengan penelitian Priyanka et al., Bashir menyatakan bahwa posisi duduk rileks dengan sudut sekitar 90- $120^{\circ}$ dianggap memenuhi kriteria duduk yang baik secara ergonomik. ${ }^{16}$

Terjadi nyeri lebih sering pada saat posisi duduk membungkuk dan tegak karena pada posisi ini otot-otot erektor spina lebih sering berkontraksi sehingga lebih cepat terjadi ketegangan yang berlebihan. Mobilitas dan fleksibilitas juga berkurang pada ligamentum longitudinal anterior dan posterior. Hal yang sama terjadi pada jaringan ikat di vertebra, yang bila terjadi gangguan akan menyebabkan nyeri. Secara struktural, jaringan ikat terdiri dari tiga golongan komponen; sel, serat, dan substansia dasar. Berbeda dari jaringan lain yang mempunyai komponen utama sel, unsur pembentuk utama dari jaringan ikat ialah matriks ekstrasel. Matriks ekstrasel terdiri dari kombinasi berbagai serat protein (kolagen, retikulin, elastin) dan substansia dasar. Serat-serat ini, terutama serta kolagen, membentuk tendo, aponeurosis, simpai organ, dan membran pembungkus sistem saraf pusat (meningen). ${ }^{17}$

Gangguan pada ligamentum khususnya ligamentum longitudinalis posterior yang meregang pada segmen vertebra lumbalis serta otot-otot paravertebra yang menegang merupakan hal tersering yang menyebabkan NPB. ${ }^{5,18}$ Seringnya terjadi 
gangguan pada daerah vertebra lumbalis dikarenakan segmen vertebra ini hanya memiliki lapisan tipis dibandingkan segmen vertebra yang lain. ${ }^{16}$ Selain itu, segmen ini memang merupakan segmen yang paling mobile di antara segmen vertebra lainnya. Hal ini disimpulkan berdasarkan pengamatan sudut lumbosakral, ketebalan diskus intervertebralis di segmen vertebra L4-L5, serta perbandingan intensitas nyeri yang terjadi pada ketiga posisi tersebut. Dikatakan bahwa intensitas NPB pada posisi bersandar paling rendah dibandingkan posisi membungkuk dan posisi duduk yang tegak tanpa sandaran. Penelitian lain mengatakan bahwa posisi duduk yang cenderung membungkuk berpotensi menyebabkan hernia nukleus pulposus (HNP) sehingga terjadi kompresi pada radiks saraf. Hal ini terjadi karena pada duduk membungkuk, posisi segmen vertebra antara lumbal dan sakral cenderung memudahkan diskus vertevbralis untuk keluar dan menekan saraf yang terletak posterior dari diskus. ${ }^{16}$

\section{Lama duduk}

Responden yang menghabiskan waktu untuk duduk bekerja rata-rata 7-8 jam berjumlah 23 orang, sedangkan yang menghabiskan waktu untuk duduk bekerja 9-10 jam 24 orang.

Bekerja dengan lama duduk statis pada rentang waktu 1,5-5 jam berpeluang 2,35 lebih besar mengakibatkan NPB dibandingkan hanya bekerja $<1,5$ jam. Emami et al. menyatakan dalam penelitiannya bahwa perempuan yang duduk lama selama $>4$ jam berpengaruh menimbulkan NPB. Demikian pula Sumekar dan Natalia ${ }^{19}$ menyatakan bahwa lama duduk $>4$ jam menyebabkan terjadinya NPB pada hampir seluruh sampel penelitian.

NPB sudah dialami oleh 30 responden pada pukul 08.00-10.59 serta oleh 31 responden pada pukul 11.00-13.59. Dianjurkan bagi karyawan setiap 1 jam mengambil waktu selama beberapa menit untuk meregangkan otot-otot yang berkontraksi oleh karena pada 15-20 menit setelah awal bekerja biasanya otot-otot sudah mulai mengalami kelelahan. ${ }^{20}$

Terlalu lama duduk menyebabkan penambahan beban. Penambahan beban yang bersifat kontinu mengakibatkan gangguan dan bila terlalu lama tidak ditangani dengan benar dapat menyebabkan kerusakan jaringan pada segmen vertebra, terutama segmen vertebra lumbalis. ${ }^{21}$ Duduk lama meningkatkan kecenderungan berposisi duduk statis, yang mengakibatkan oksigenasi ke diskus, ligamentum, otototot, dan jaringan lainnya terganggu, sehingga timbul rasa nyeri atau tidak nyaman di area punggung bawah. ${ }^{22}$

Terjadinya peningkatan sirkulasi darah, penurunan kerja otot, serta berkurangnya tekanan pada kolumna vertebralis dan diskus intervertebralis merupakan rangkaian dampak positif posisi duduk di tempat duduk yang melibatkan ergonomik. ${ }^{23}$

\section{Keterbatasan penelitian}

Keterbatasan pada penelitian ini, antara lain: analisis multivariat tidak dilakukan; tinggi badan (TB) dan berat badan (BB) tidak dianalisis, padahal kedua hal ini penting sebagai faktor risiko NPB mekanik; ergonomik, dalam hal ini sarana kerja (kursi dan meja) tidak dianalisis lengkap; dan manfaat pada instansi belum dilaksanakan karena keterbatasan waktu.

\section{SIMPULAN}

Dari hasil penelitian disimpulkan bahwa terdapat hubungan bermakna antara posisi duduk dan lama duduk dengan nyeri punggung bawah mekanik kronik pada karyawan bank.

\section{UCAPAN TERIMA KASIH}

Ucapan terima kasih ditujukan kepada dr. Theresia I. Mogi, SpRM selaku penguji Skripsi dan semua pihak yang secara langsung maupun tidak langsung telah menumbuhkan ide atau gagasan pada penulis. 


\section{DAFTAR PUSTAKA}

1. Eko PT, Putra IGNP. Diagnosis dan tatalaksana nyeri punggung bawah. Medicina. 2009;40:109-14.

2. Cohen SP, Argoff CE, Carragee EJ. Management of low back pain. Clinical review. BMJ. 2009;338:100-6.

3. Nachemson AL. The lumbar spine an orthopaedic challenge. Spine. 1976;1:59-71.

4. Effendi F, Wawolumaja C, Azwar A, Misbach J. A risk prediction of the incidence of occupational low back pain among mining workers. Med J Indones. 2011;20:212-6.

5. Deyo RA, Weinstein JN. Low back pain. N Eng J Med. 2001;344:363-70.

6. Ehrlich GE. Low back pain. Bulletin of the World Health Organization. 2003;81:671-6.

7. Pajek MB, Cuk MP, Pajek J. Low back pain in physically active young adults. Zdrav vestn. 2012;81:205-17.

8. Openshaw S, Taylor AE, Allsteel. Ergonomics and Design A Reference Guide [homepage on the Internet]. 2006 [cited 2013 Aug 07]. Available from: http://cms.allsteeloffice.com/SynergyD ocuments/ErgonomicsAndDesignRefer enceGuideWhitePaper.pdf.

9. North Carolina Department of labor. A Guide to Ergonomics. USA: N.C. Department of Labor, Occupational Safety and Health Program; 2009.

10. International labour organization (ILO). Your health and safety at work: ergonomics. actrav. Available from: itcilo.org/actrav

english/telearn/osh/ergo/ergonomi.htm.

11. Sweere HC. Ergonomic factor involved in optimum computer workstation design: A pragmatic approach [homepage on the INternet]. 2002 [cited 2013 Aug 07]. Available from: http://www. ergotron.com/portals/0/literature/whitep apers/english/ergonomic_factors.pdf

12. O'Sullivan K, O'Dea $P$, Dankaerts W, O'Sullivan P, Clifford A, O'Sullivan L. Neutral lumbal spine sitting posture in pain-free subjects. Man Ther. 2010;15(6):557-61.
13. Alemo S, Sayadipour A. Chronic mechanical low back pain. J Neurolog Orthop Med Surg. 2006;28(1):5-6.

14. Purnamasari H, Gunarso U, Rujito $L$. Overweight sebagai faktor resiko low back pain pada pasien poli saraf RSUD Prof. Dr. Margono Soekarjo Purwokerto. Mandala of health. 2010;4:26-31.

15. Tana L, Halim FXS. Determinan nyeri pinggang pada tenaga paramedis di beberapa rumah sakit di Jakarta. J Indon Med Assoc. 2011;61(4):155-9.

16. BBC News. Sitting straight 'bad for backs'. [cited 2006 Nov 28].

17. Sarkar PA, Shigli AL. Ergonomics in general dental practice. People's Journal of Scientific Research. 2012;5(1):56-9.

18. Freitas KP, deBarros SS, Angelo R, Uchoa E. Occupational low back pain and the sitting position: effects of labor kinesiotherapy. [Original article]. Rev dor Sao Paulo. 2011;12:308-13.

19. Sumekar DW, Natalia D. Computer operator's low back pain causing sitting position and duration. Bandung Medical Journal Universitas Padjajaran. 2010;42(3):123-7.

20. Safitri, Ambar I. Hubungan lama posisi duduk terhadap nyeri punggung bawah pada pegawai rental komputer di Kentingan Surakarta. [skripsi]. Surakarta: Universitas Muhammadiyah Surakarta; 2010.

21. Samara D, Basuki B, Jannis J. Duduk statis sebagai faktor risiko terjadinya nyeri punggung bawah pada pekerja perempuan. Universa Medicina. 2005;24:76-9.

22. Mangrum S. Prolonged sitting: association with low back pain and proposed solutions [homepage on the Internet]. c2006 [cited 2013 Aug 07]. Available from: http://www.backexercisedoctor. com/journal/2010/3/23/prolongedsitting-association-with-low-back-painand-propose.html.

23. New South Wales Government. Health and safety in the office, Guide 2004. NSW: WorkCover NSW; 2004; p.5-16. 